\title{
МЕТОДОЛОГІЧНІ ОРІЕНТИРИ ЕКЗИСТЕНЦІАЛЬНО-СУБ'ЕКТНОГО ПІДХОДУ ДО ДОСЛІДЖЕННЯ КОМУНІКАТИВНОї ДІЯЛЬНОСТІ У ДОШКІЛЬНИКІВ ІЗ ЗАТРИМКОЮ ПСИХІЧНОГО РОЗВИТКУ
}

Ірина Омельченко, Інститут спеціальної педагогіки Національної академії педагогічних наук України, м. Київ, Україна, iraomel210781@ukr.net

3'ясовано, що об'єднуючою ознакою сучасних підходів до розуміння комунікативної діяльності $€$ екзистенціально-онтологічний, аксіологічний, екзистенціально-смисловий виміри, що відповідають інтерсуб'єктній парадигмі психологічного пізнання і взаємодії людей. Використання екзистенціально-суб'єктного наукового підходу дало можливість, по-перше, з'ясувати значення дослідження діалогу як екзистенціальної події; по-друге, визначити, що осягнення інтер-, інтрасуб'єктного та парасоціального виміру комунікативної діяльності дитини та їі психічних, душевних і духовних виявів вимагає нетрадиційної екзистенціально-онтологічної, органічно-духовної методології розуміння і інтерпретації феноменів. Для дослідження цілісної фрункціональної структури комунікативної діяльності у вимірі Я-Інший (Я-Інший Я) і закономірностей ї̈ реалізації була обґрунтована методологія дослідження: когнітивна, герменевтична, наративна, екзистенціальна. Теоретично обгрунтовано основоположні принципи дослідження комунікативної діяльності у вимірі Я-Інший (Я-Інший Я): структурно-генетичний, суб'єктності, культурного контекстуалізму, онтологічного конструктивізму, інтеграції, єдності методологічних, діагностичних, корекційно-розвивальних і психокорекційних інтервенцій; диференціального підходу.

Ключові слова: екзистенціально-суб'єктний підхід, комунікативна діяльність, спілкування, методологія, принципи, затримка психічного розвитку, дошкільники.

Ирина Омельченко, Институт специальной педагогики Национальной академии педагогических наук Украины, г. Киев, Украина

Методологические ориентиры экзистенциально-субъектного подхода к исследованию коммуникативной деятельности у дошкольников с задержкой психического развития

Выяснено, что объединяющей особенностью современных подходов к пониманию коммуникативной деятельности является экзистенциально-онтологическое, аксиологическое, экзистенциально-смысловое измерения, которые соответствуют интерсубъектной парадигме психологического познания и взаимодействия людей. Использование экзи(c) Омельченко І., 2018 
стенциально-субъектного научного подхода позволило, во-первых, выяснить значение исследования диалога как экзистенциального события; во-вторых, определить, что постижение интер, интрасубьектного и парасоциального измерения коммуникативной деятельности ребенка и его психических, душевных и духовных проявлений требует нетрадиционной - экзистенциально-онтологической, органично духовной методологии понимания и интерпретации феноменов. Для исследования целостной функциональной структуры коммуникативной деятельности в измерении Я-Другой (Я-Другой Я) и закономерностей ее реализации была обоснована методология исследования: когнитивная, герменевтическая, нарративная, экзистенциальная. Теоретически обосновано основополагающие принципы исследования коммуникативной деятельности в измерении Я-Другой (Я-Другой Я): структурно-генетический, субъектности, культурного контекстуализма, онтологического конструктивизма, интеграции, единства методологических, диагностических, коррекционно-развивающих и психокоррекционных интервенций; диффреренциациального подхода.

Ключевые слова: экзистенциально-субъектный подход, коммуникативная деятельность, общение, методология, принципы, задержка психического развития, дошкольники.

Iryna Omelchenko, Institute of Special Pedagogy, the National Academy of Educational Sciences of Ukraine, Kyiv, Ukraine

Methodological guide within the existential-subjective approach for researching on communicative activities of primary school children with developmental delay

The article shows that the unifying feature of modern approaches to communicative activity understanding is the existential-ontological, axiological, existential-semantic planes that correspond to the intra-subjective paradigm of psychological knowledge and people interactions. The existential-subjective scientific approach allowed us, firstly, to determine significance of a dialogue as an existential event; secondly, to determine that comprehension of the inter-, intra-subjective and para-social planes of children's communicative activities and their mental, spiritual and spiritual manifestations requires an non-traditional - existential-ontological, organicspiritual - methodology for understanding and interpretation of the phenomena. The existentialsubjective scientific approach for researching on motivational-intentional, epistemologicalaffective, reflective-semantic and reflexive-value functions of communicative activities will be implemented through revealing of the specificity of contacts occurring within the limits of Self and inter-subjective interactions with adults and peers, which is embodied in a system of attitudes. The reflexive-semantic function of communicative activities is revealed through understanding of a position and its mentalization; and the reflective-value function is realized through intra- and para-social communicative relations, symbolization, verbalized internal dialogue and decentration, which present an inter-subjective relations with the Other in culture. The research methodology has been substantiated: cognitive, hermeneutic, narrative, and existential in order to study the integral functional structure of communicative activities on I - the Other (I - the Other Self) planes and its objective laws. The basic principles of researching on communicative activities on $I$ - the Other (I - the Other Self) plane are theoretically substantiated: structural-genetic, subjectivity, cultural contexts, ontological

«ОСОБЛИВА ДИТИНА: навчання і виховання», № 4, 2018 
constructivism, integration, unity of methodological, diagnostic, corrective-developmental and psycho-correctional interventions; the differential approach.

Keywords: existential-subjective approach, communicative activity, communications, methodology, principles, developmental delay, preschoolers.

$\mathrm{B}$ ідповідно до визначених нами теоретико-методологічних засад дослідження діяльнісний характер комунікативної діяльності на сучасному етапі в умовах інформаційного суспільства та постнеокультури має бути доповнений вивченням суб'єктних модусів взаємодії із Іншим в умовах соціуму, культури та у просторі власного $\boldsymbol{A}$ із розумінням змісту соціально-комунікативної ситуації та усвідомленням ціннісно-смислових детермінант Іншого суб'єкта, який здатний до смислового та рефлексійного спілкування.

Сучасні ідеологеми та методологеми інтерсуб'єктної парадигми до дослідження комунікативної діяльності у вимірі Я-Інший (Я-Інший Я) втілені в екзистенціально-онтологічному, аксіологічному, екзистенціально-смисловому підходах. Відповідно, ми вважаємо за необхідне інтегрувати ці підходи в екзистенціальносуб'єктний науковий підхід. Вище зазначене, спонукає нас до необхідності його обгрунтування.

У руслі визначеного нами підходу набуває ваги дослідження діалогу як екзистенціальної події (Н. Большунова, Л. Воробйова, Г. Дьяконов, Н. Непомняща, О. Устинова та ін.) $[1 ; 3 ; 4 ; 9 ; 15]$. Основний акцент підходу спрямований на те, що діалог мислиться як явище духовного, а не інформаційного характеру. Названий ракурс дослідження є важливим у контексті розгляду рефлексійносмислової і рефлексійно-ціннісної функцій комунікативної діяльності дошкільників із ЗПР, позаяк саме на рівні цих функцій відбувається утілення розуміння і співрозуміння з Іншим означеного смислом.

Саме тому, метою статті є з'ясування методологічних орієнтирів до дослідження комунікативної діяльності в дошкільників із ЗПР. Визначена нами мета потребує, по-перше, теоретичного обгрунтування ключових позицій екзистенціально-суб'єктного наукового підходу до дослідження комунікативної діяльності у вимірі Я-Інший (Я-Інший Я); по-друге, визначення принципів дослідження усвідомленої комунікативної діяльності у дошкільників із ЗПР.

Для Л. Воробйової центральною категорією, поза зв’язком з якою неможливим є розуміння діалогу, є категорія «смисл». Діалог розгортається у просторі смислу - співрозмовники повинні бути зацікавлені один в одному адже саме в діалозі відбувається породження смислу, що свідчить про зустріч двох свідомостей. Дослідниця зауважує, що емоційної близькості для діалогу ще недостатньо, а необхідним є проникнення в глибинні смисли особистості та розуміння Іншого [3].

Так, зовнішній і внутрішній діалог розгортається не в предметному, а в екзистенціальному просторі, тобто в ситуації, де має бути досягнутий не предметний результат, а смисл, причому не смисл діяльності, і не смисл того чи іншого висловлювання співрозмовника, а мого «тут-і-тепер існування». 
Осягнення інтер-, інтрасуб'єктного та парасоціального виміру комунікативної діяльності дитини та іiі психічних, душевних і духовних виявів вимагає нетрадиційної - екзистенціально-онтологічної, органічно-духовної методології розуміння й інтерпретації феноменів. За переконанням Г. Дьяконова, дослідження комунікативної діяльності від контакту до рефлексії передбачає процес переходу до розуміння та інтерпретації Іншого (тобто, з суб'єкт-об'єктного впливу діалог перетворюється на суб'єкт-суб’єктну взаємодію). При цьому дослідження діалогічних явищ стає не тільки науковим і об'єктивним, але також гуманітарним і суб'єктивним [4]. Це змінює сутнісний характер дослідження комунікативної діяльності у вимірі Я-Інший (Я-Інший Я) і перетворює його на гуманітарно-творчий процес взаєморозуміння та взаємоінтерпретації, на процес взаємного утвердження людяності учасників діалогу.

Отже, дослідження комунікативної діяльності у вимірі Я-Інший (Я-Інший Я) передбачає застосування нетрадиційних, некласичних методів науково-психологічного дослідження. Такими виступають методи наративу, невербальної взаємодії, проективні методи психодіагностики, психосемантичні методи тощо. У діалогічному спостереженні інтерсуб'єктна взаємодія трансформується в інтрасуб'єктну, а почасти й парасоціальну, а відтак завдяки надситуативній позиції уяви і символічній функції задає обрії суб'єктивно-смислового розуміння комунікативної події, що сприймається, і тому відіграє принципово важливу роль. Унаслідок цього діалогічне спостереження стає співчуваючим, інтерпретуючим, розуміючим, проникаючим, осягаючим, і наближається до того виміру життя людини, який називають спогляданням. Отже, діалогічне спостереження - це екзистенціально-онтологічне сприймання і переживання людини та світу, тобто розуміюче, «причетне» споглядання.

Діалог, як екзистенціальна подія, виникає у текстах як соціокультурне явище, як особливий «голос», висловлений у всіх його формах, зокрема вербальній, музичній, графічній та вчинок. Текст, як «зв'язний знаковий комплекс», містить у собі те, що, на думку М. Бахтіна, «має відношення до істини, правди, добра, краси, історії, і виступає як «третій» голос у діалозі згоди (Н. Большунова). Дослідниця зауважує, що дитина вступаючи в діалогічні, суб'єктні відносини зі світом та іншими людьми, завжди опосередковує цей діалог текстами, як носіями абсолютних об'єктивних цінностей, тобто завжди виходить за межі соціальності в соціокультурний простір. Соціокультурні зразки, система абсолютних цінностей представлена людині у формі текстів. У ранньому віці відбувається рефлексія індивідуальності, усвідомлення відмінностей від інших людей і предметного світу, вияв відповідальності у формі переживання (співчуття) до близьких і всього, що дитина олюднює. У якості соціокультурного зразка виступають забавлянки, іграшки, кумулятивні казки. Дошкільний вік характеризується виявом та неусвідомленою рефлексією образу «світлого» (позитивного) як протилежного «темному» на основі казок як особливого соціокультурного тексту, становленням відповідності соціокультурним зразкам, представленим у розповіді, виявом вибору та вчинку (вибором способу дій відповідно до соціокультурних зразків) в умовах ігрової діяльності та спіл-

«ОСОБЛИВА ДИТИНА: навчання і виховання», № 4, 2018 
кування у формах близькості (любові, прийняття) у стосунках із дорослими та однолітками [1].

Подібного екзистенціально-суб'єктного модусу дослідження комунікативної діяльності дотримується Н. Непомняща, О. Устинова [9; 15]. Психологиня О. Устинова зауважує, що рефлексія реалізується у формі переживання себе, що відбувається в діалозі як події зі Світом, а iï засобом виступає здатність відповідати смислам, які перебувають у світі [15]. Мірою рефлексійного діалогу виступають соціокультурні зразки. Авторка, обстоюючи позицію Н. Непомнящої, відзначає, що через ставлення людини до Світу відкривається особливий взаємозв'язок 3 іншими людьми, що характеризується «здатністю ототожнення себе з іншими», ця здатність позначається як «здатність бути собою та Іншим» [9].

Рефлексійний вихід за межі усталених для себе уявлень про світ і про власне $Я$ в соціокультурний простір є основою розвитку співбуттєвого стосунку з Іншим у культурі, на основі якого стає можливим розвиток здатностей до співпраці та співрозуміння дошкільника із ЗПР із дорослими та однолітками. Так, через внутрішній діалог дитина відкриває цінності «свого» внутрішнього світу та світу «іншого».

Реалізація екзистенціально-суб'єктного наукового підходу в раках дослідження мотиваційно-інтенційної, гносеологічно-афективної, рефлексійно-смислової і рефлексійно-ціннісної функцій комунікативної діяльності буде втілена через з'ясування специфіки контакту, що постає у рамках $A$ та інтерсуб'єктній взаємодії з дорослими та однолітками, яка втілюється у системі ставлень. Рефлексійно-смислова функція комунікативної діяльності розкривається через розуміння позиції і менталізацію, а рефлексійно-ціннісна втілюється через систему інтра- та парасоціального комунікативного стосунку, символізацію, вербалізований внутрішній діалог та децентрацію. Теоретично обгрунтований концепт усвідомленої комунікативної діяльності у вимірі Я-Інший (Я-Інший Я) вимагає найбільш релевантного інструментарію дослідження специфіки інтерсуб'єктної взаємодії 3 дорослими та однолітками, що вимагає аналізу праць О. Волкової, В. Знакова, О. Зубової [2; 5; 6], в межах яких окреслюється феноменологія суб'єктності, розуміння і співрозуміння з Іишим.

Суб'єктність, у відповідності з поглядами О. Волкової, як ставлення передбачає емоційний відгук на себе та на іншу людину в комунікативному стосунку з нею, а розуміння виступає одним із найважливіших психологічних феноменів, що пронизує інтерсуб'єктний стосунок, що поступово трансформується в інтрасуб'єктний та парасоціальний. Розуміння спрямоване на породження смислу явищ, подій, ситуацій у всіх трьох реальностях, у яких живе дитина - емпіричній, соціокультурній і екзистенціальній. У психології їм відповідають три традиції дослідження - когнітивна, герменевтична та екзистенціальна (В. Знаков) [5].

Описану модель В. Знакова вважаємо за доцільне експлікувати в теоретико-експериментальному дослідженні феноменології і ноуменології комунікативної діяльності у вимірі Я-Інший (Я-Інший Я). Науковець уважає, що дослідження, того що відноситься до емпіричної реальності здійснюється психологами 3 позицій когнітивної традиції; спосіб розуміння світу парадигматичний; підстави 
розуміння-знання і значення; тип розуміння - розуміння-знання. Соціокультурній реальності відповідає герменевтична традиція психологічних досліджень; наративний спосіб розуміння світу; підставою розуміння є думка (позиція) і смисл; у результаті з'являється тип розуміння-інтерпретація. Екзистенціальна реальність: екзистенціальна традиція; тезаурусний спосіб розуміння; переживання і досвід; розуміння-осягнення [5].

Відповідно до вищезазначеного, поєднання когнітивної, герменевтичної i екзистенціальної традиції психологічного дослідження необхідне при вивченні контакту (мотиваційного компонента) комунікативної діяльності. Когнітивна традиція представлена в дослідженні (інтерсуб'єктного компонента), і більшою мірою втілює здатність до вибудовування системи інтерсуб'єктних взаємодій у яких відбувається пізнання і емоційне ставлення до Інших, а відтак задіюються окрім когнітивних процесів ще й смислові, що зумовлює доречність застосування як когнітивної, так і герменевтичної методології. Рівень смислового спілкування (смисловий компонент) передбачає здатність розуміти ментальні стани Іншого, що, відповідно, вимагає застосування герменевтичної традиції психологічних досліджень. Рівень рефлексійного спілкування передбачає актуалізацію надситуативної позиції уяви та розгортання інтрасуб'єктного чи парасоціального стосунку, в руслі яких через пред'явлення символу запускається внутрішній діалог, i, відповідно, через переживання відбувається зіштовхування в полі свідомості різних ціннісно-смислових позицій (децентрація) 3 метою встановлення співрозуміння, відповідно до екзистенціальної традиції дослідження [10].

Одним із ключових модусів реалізації екзистенціально-суб'єктного наукового niдxоду в рамках нашого дослідження визначається з'ясування специфіки інтрасуб'єктної взаємодії із уявним компаньйоном і улюбленою іграшкою, які виступають утіленням комунікативного стосунку з персоналізованим Іншим. Персоналізований Інший «живе» у внутрішньому просторі суб'єкта та забезпечує здатність до присвоєння соціокультурного досвіду спілкування з різними психологічними системами (дорослими та однолітками). Існування інтрасуб'єктного та парасоціального типів взаємодії (з персоналізованим та символічним Іншим) зумовлене необхідністю дії в надситуативному контексті, який актуалізується в ситуаціях невизначеності взаємин (стрес, конфлікт, фрустрація). У таких ситуаціях постає необхідність у рефлексійно-комунікативній дії (позначеній цінністю та смислом), яка запускається за посередництва психологічних механізмів символізації, внутрішнього діалогу та децентрації.

В основу екзистенціально-суб'єктного наукового підходу покладено низку принципів, дотримання яких у дослідженні комунікативної діяльності дошкільників із ЗПР забезпечить розуміння їі суті, джерел та психологічних механізмів функціонування в умовах затриманого та типового розвитку. Дослідження комунікативної діяльності на засадах екзистенціально-суб'єктного наукового підходу передбачає обгрунтування принципів, характерних для постнекласичного етапу розвитку психології (С. Максименко, М. Савчин, І. Тітов та ін.).

На думку М. Савчина, принципи, будучи ядром наукового методу, поєднують і організовують конкретні методи і прийоми в єдине ціле, поєднують демар-

«ОСОБЛИВА ДИТИНА: навчання і виховання», № 4, 2018 
кацію науки від ненауки. Ще одна важлива функція методологічних принципів - евристична, вони регулюючи науково-дослідну діяльність, спрямовують науковий пошук [12].

Розробка теоретико-методичного апарата діагностики комунікативної діяльності здійснювалася нами на основі загальних принципів психодіагностики (Л. Бурлачук, Ю. Забродін, К. Гуревич та О. Борисова та ін.), принципів суб'єктного підходу (В. Дружинін), методологічних принципів дослідження в постнекласичній психології (І. Тітов) [13; 14], та з використанням теоретикометодичного інструментарію вивчення дітей із затримкою психічного розвитку (Т. Вісковатова, О. Дмітрієва, І. Коробейніков та О. Інденбаум, К. Лебединська, В. Лубовський, Н. Стадненко та Т. Ілляшенко, А. Обухівська Л. Прохоренко, Т. Сак, М. Сємаго, У. Ульєнкова та О. Лєбедєва, та ін.).

У якості основоположних принципів дослідження комунікативної діяльності у вимірі Я-Інший (Я-Інший Я) нами визначено: структурно-генетичний, суб'єктності, культурного контекстуалізму, онтологічного конструктивізму, інтеграції, єдності методологічних, діагностичних, корекційно-розвивальних і психокорекційних інтервенцій; диференціаціального підходу.

Структурно-генетичний принщип орієнтує на розкриття (у співвідношенні з різними рівнями причинності) процесуальних аспектів структурно-функціональної організації та самоорганізації психічних феноменів. Система, а саме комунікативна діяльність у вимірі Я-Інший (Я-Інший $Я$ ) має вивчатися в структурнодинамічному, хронологічному та каузально-детермінаційному аспектах.

Система утворюється різнорідними структурними компонентами, динамічні зв'язки між якими забезпечують їі цілісне інтегративне функціонування. 3 цими вихідними якостями системи співвідносяться базові характеристики будь-якого процесу розвитку, унаслідок чого він постає як поява властивостей цілісної системи та може бути зрозумілим лише в термінах складної взаємодії їі компонентів.

Дослідження структурно-рівневої організації комунікативної діяльності у вимірі Я-Інший (Я-Інший Я) має поєднуватись із вивченням процесуальних аспектів ії розвитку. У цьому випадку структурно-синхронічне вивчення складного ієрархізованого об'єкта передбачає одночасний аналіз і його генетично-діахронічних характеристик (А. Брушлінський, Д. Завалишина та В. Барабанщиков, Б. Ломов, С. Максименко та ін.). Інтегральність комунікативної діяльності у вимірі Я-Інший (Я-Інший Я) передбачає застосування різних психодіагностичних процедур, а також застосування методів багатовимірної статистики з метою визначення типології їі розвитку.

Принщип суб'єктності дає можливість розглядати дитину при аналізі іiі психіки не як сукупність окремих іiі психічних функцій і когнітивних параметрів, слабко пов'язаних характеристик та індивідуальних властивостей діяльності й поведінки, як це відбувається у традиціях функціональної і когнітивістської психології, а як єдине ціле з усіма ії індивідуальними властивостями і виявами, коли вона сама (як суб'єкт) розвиває, організує і контролює свою активність (К. Абульханова, А. Брушлинський, С. Кузікова, О. Осницький, В. Татенко та ін.). 
Принцип суб'єктності у контексті дослідження комунікативної діяльності у вимірі Я-Інший (Я-Інший Я) наголошує на необхідності переходу інтерсуб'єктної взаємодії в інтрасуб'єктний та парасоціальний ії типи, що дає змогу особистості пізнавати та продуктивно перетворювати предметну реальність (і навіть власну психіку), позаяк за такої умови відбувається проектування своєї комунікативної діяльності, здійснення рефлексійної саморегуляції, інтегрування та мобілізування психічних ресурсів з метою досягнення поставлених комунікативних цілей.

Важливо, що такі характеристики суб'єктності, як активність і надситуативність забезпечують здатність дитини долати наявні суперечності. Визначення суб'єкта як такого, що розв'язує супротивністі, дає можливість зрозуміти, необхідність дослідження смислового та рефлексійного компонента комунікативної діяльності як ресурсу комунікативної дії в ситуації невизначеності взаємин.

3 вищезазначеного, випливає необхідність діагностики тих мотиваційних, когнітивно-афективних, рефлексійно-смислових та рефлексійно-ціннісних механізмів, які визначають довільний вибір дошкільником певної стратегії й тактики комунікативних дій відповідно до специфіки ситуації та власними переживаннями.

Принщип культурного контекстуалізму передбачає, що комунікативна діяльність дошкільника у вимірі Я-Інший (Я-Інший Я) має тлумачитись із урахуванням соціокультурного контексту та його задіяності у цей контекст, що відповідно дає змогу розглянути особистість у фокусі їі психокультурного розвитку та виокремити у системі її детермінації провідні культурні чинники (Г. Акопов, В. Грачьов, І. Докучаєв, А. Соколов та ін.). Саме цим і зумовлена необхідність дослідження взаємодії з символічним Іншим, який міститься у матриці культури (в інтерсуб'єктній взаємодії з дорослими та однолітками засобами цінностей, які дають можливість децентрувати власну суб'єктність, і через інтеріоризацію парасоціального стосунку з анімаційним персонажем осмислити багатоманітність своєї позиції з метою встановлення спів-значення як основи співбуттєвого стосунку).

Отже, вивчення культурогенної рефлексійно-ціннісної функції комунікативної діяльності дошкільника із ТПР і ЗПР та його багатовимірних культурних ідентифікацій з Іншим, змістовно розкрие процес набуття індивідом здатності до досягнення співрозуміння, діалогу, рефлексії свого життя-в-культурі. Завдяки рефлексійно-ціннісній функції комунікативної діяльності дошкільника відбувається оволодіння ним конкретними культурними формами, їх творче присвоєння в індивідуально-своєрідну цілісність власної суб'єктності та наступна трансляція певних його змістів назовні у вигляді текстів, образів, цінностей, смислів тощо.

Відповідно, мішенню психодіагностики має виступати взаємодія особистості з Іншим у персональному та культурному просторі, що втілюється через вивчення модусів інтрасуб'єктної та парасоціальної взаємодії із відповідною ії трансформацією в співбуттєвий комунікативний стосунок з дорослими та однолітками в умовах інформаційного суспільства та постнеокультури.

Принщип онтологічного конструктивізму орієнтує на осмислення комунікативної діяльності не в термінах причин і наслідків, а в термінах інтенцій, планів, взаємодій, колективних процедур, практик. У центрі дослідження опиняється символічна взаємодія. Застосування названого принципу уможливить вивчен- 
ня комунікативної діяльності як продукту соціокультурного конструювання, у процесі якої відбувається не лише інформаційний обмін, а й продукується певна гама почуттів, цінностей і смислів (В. Петренко, І. Тітов та ін.).

Сутність принципу онтологічного конструктивізму в аспекті дослідження комунікативної діяльності в ціннісно-смисловому вимірі розкрита І. Тітовим. Він зауважує, що в онтологічному аспекті символічна взаємодія особистості розглядається як певний спосіб існування людини - як ii буття-взаємодія з репрезентаціями онтологічно Іншого (внутрішньоособовим, позаособовим, безособовим, надособовим), що має відмінні фундаментальні предикати. Інтимним механізмом такого двостороннього, реляційного співбуття $\epsilon$ «розімкнення» дитини у напрямі Іншого та здійснення нею онтологічного трансцензусу, що й конституює особистісну реальність [13].

Експлікація принципу онтологічного конструктивізму уможливлює дослідження у структурі комунікативної діяльності виміру інтрасуб'єктної взаємодії (на моделі улюбленої іграшки та уявного компаньйона) у дошкільників із ЗПР шляхом аналізу сконструйованих ними семіотичних моделей (знаковосимволічних репрезентацій світу та Іншого), що використовуються для впорядкування й надання смислу індивідуальному та інтерсуб'єктивному досвіду, для осягнення світу й саморозуміння себе у світі, опосередкування та організації комунікативної дії в надситутивному контексті та ситуаціях невизначеності взаємин. Важливого ракурсу в заявленому дослідницькому фокусі набуває вивчення мотиваційно-інтенційної функції комунікативної діяльності, у рамках якої окрім інтерсуб'єктних психологічних меж важливим джерелом контакту постають інтрасуб'єктні психологічні межі, позаяк вони вибудовуються всередині $Я$ суб'єкта і презентують відносини $Я$-не-Я. Можливість визначати себе через Іншого, а Іншого через себе та постають основним принципом, згідно з яким формується суб’єктивність, а пізніше і - суб’єктність дитини.

Здатність до рефлексійно-ціннісної символічної функції (за посередництва цінності) сприятиме трансформації особистісного смислу і децентрації власної суб'єктності, на основі якої стане можливим утілення співпраці та досягнення співрозуміння в інтерсуб’єктній взаємодії з Іншим. Застосування на рівні емпіричного дослідження принципу онтологічного конструктивізму зумовлює доречність оперування психосемантичними, проективними та якісними (описово-інтерпретативними) формами дослідницького пошуку.

Принцип інтегращії передбачає здійснення в єдиній системі наукової діяльності міжпарадигмального та міждисциплінарного діалогу, поєднання різних методичних підходів і дослідницьких стратегій, конструктивну взаємодію різних фундаментальних і прикладних знань (Г. Балл, М. Гусєльцева, В. Кобильченко, М. Супрун, А. Юревич та ін.).

Так, у міждисциплінарному дослідженні комунікативної діяльності створюються умови для інтеграції (у гносеологічному аспекті) наукового знання, що проявляється у прагненні до синтезу наявних теорій моделей, які описують окремі аспекти психічної реальності через наведення «концептуальних мостів». Зазначений принцип наголошує на тому, що для адекватного та, за можливіс- 


\section{[NAVRA}

тю, різновекторного опису й дослідження феномену комунікативної діяльності необхідне конструктивне поєднання накопичених у руслі різних теоретичних напрямів знань про неї та синтез номотетичного й ідіографічного методичних підходів до їі вивчення $[4 ; 5 ; 7 ; 11 ; 12 ; 14]$.

Для номотетичного (природничого, пояснювального, експериментального, психометричного) підходу є характерним об'єктивне вивчення дитини за допомогою індуктивного методу, спрямованого на виявлення загальних закономірностей життєдіяльності об'єкта, а для ідеографічного (гуманітарного, описового, суб'єктивно-феноменологічного, проективного, якісного) підходу - ціннісно-смислове освоєння особливого, одиничного людського буття на основі актів розуміння і переживання $[4 ; 5 ; 7 ; 11 ; 12 ; 14]$.

Однак, хочемо зауважити, що в рамках дослідження комунікативної діяльності у вимірі Я-Інший (Я-Інший Я) діагностика передбачає пріоритет гуманітарного підходу над природничо-науковим. Психодіагностика, яка орієнтується на природничо-науковий підхід, не передбачає врахування індивідуальності психіки. Однак, головною формою існування психічного є його індивідуальна неповторність, активність і самоактивність. Оскільки, комунікативна діяльність у вимірі Я-Інший (Я-Інший Я) є надскладним об'єктом їі вивчення стає можливим тільки за умови застосування гуманітарного підходу.

Методологічна настанова на індивідуалізацію психологічного дослідження комунікативної діяльності у вимірі Я-Інший (Я-Інший Я) (як це має місце під час застосування ідіографічної стратегії) в кінцевому результаті повинна співвідноситися та узгоджуватися з конкретними унікальними випадками, ілюструватись ними. Зазначене уможливить доповнення, уточнення та поглиблення наукового уявлення про комунікативну діяльність шляхом розкриття ії одиничних, особливих та загальних детермінант, i, як результат, - цілісне та нередуковане iii розуміння, опосередковане об'єктивним психологічним знанням.

Принцип єдності методологічних, діагностичних, корекційно-розвивальних $i$ психокорекційних інтервениій. Цей принцип передбачає тісний зв'язок теоретичних положень діагностики з використанням інструментарію, побудованого на основі цієї методології. Враховуючи складність і різнокомпонентну структуру комунікативної діяльності у вимірі Я-Інший (Я-Інший Я), найбільш доречною $є$ інтеграція різних психологічних підходів у процесі діагностичних і психокорекційних інтервенцій у єдиний екзистенщіально-суб'єктний науковий підхід. Доцільність цих засад зумовлена тим, що комунікативна діяльність дошкільника у вимірі Я-Інший (Я-Інший Я) з нормативним і затриманим психічним розвитком є надскладним об'єктом впливів і передбачає орієнтацію психолога на ціннісні та соціокультурні контексти з позиції осмислення відношень «людина-світ».

Діагностичне завдання має виступати не як система стимулів, а як складова частина життєвої ситуації дитини. Реалізація цього принципу полягає у доборі таких діагностичних методик, які будуть найбільш відповідні дітям із ЗПР, і можуть розглядатися як параметри та показники їх психічного розвитку, при цьому дають можливість виявляти найбільш недостатні компоненти комунікативної діяльності. Параметри використовуються для впорядкування, сегменту-

«ОСОБЛИВА ДИТИНА: навчання і виховання», № 4, 2018 
вання й аналізу даних. Показники - це окремі складові параметрів, які визначаються як сума або співвідношення. Хоча параметри та показники є окремими поняттями, зазвичай вони вживаються разом. Саме значення параметрів і показників, а також зв'язок між цими значеннями роблять діагностичні дані змістовними. Для психодіагностики є важливими процедури розуміння, пояснення та інтерпретації. Розуміння, на відміну від пізнання, є осмисленням внутрішньої природи, інтерпретацією знання про об'єкт, у процесі якого знаходиться смисл, присутність у ньому духовного, ціннісного, особистісно значущого. У дослідженні комунікативної діяльності у вимірі Я-Інший (Я-Інший Я) метою розуміння є пошук сутності названого психологічного феномену.

Принцип диференціального підходу. Відповідно до цього принципу обгрунтовується необхідність диференціального підходу до дослідження комунікативної діяльності у вимірі Я-Інший (Я-Інший Я), що передбачає розрізнення дизонтогенетичних, поведінкових порушень й психічних розладів, характерних для дітей із затримкою психічного розвитку.

Відповідно до концептуальних позицій спеціальної психології основними клініко-психопатологічними критеріями, що відображають патогенетичні механізми затримки психічного розвитку, є інфантилізм та нейродинамічні розлади, що гальмують розвиток соціо-когнітивних механізмів комунікативної діяльності.

У сучасних клініко-психологічних дослідженнях (В. Лубовський, Г. Новікова, В. Шалімов) вказується на те, що, по-перше, крім емоційно-вольової сфери конституційна незрілість може частково впливати на різні складові психічної діяльності, по-друге, характеристика первинного порушення при уповільненому темпі формування пізнавальної діяльності не вичерпується нейродинамічними порушеннями, а включає в себе ознаки незрілості структурних компонентів окремих психічних процесів [8].

У зв'язку з тим, що комунікативна діяльність у вимірі Я-Інший (Я-Інший Я) розглядається нами більшою мірою як соціо-когнітивний, а не комунікативно-мовленнєвий (чи соціально-комунікативний) феномен у процесі їі діагностування принцип диференціації передбачає врахування типологічного розмаїття, що більшою мірою презентує специфіку психолого-педагогічного розвитку дошкільників із ЗПР і базується на врахуванні трьох типологічних груп дітей (Н. Бабкіна, I. Коробейніков та О. Інденбаум): 1 група - діти з легким дефіцитом когнітивних і соціальних здібностей, у структурі порушення яких на перший план виступають труднощі довільної регуляції діяльності та поведінки й ознаки загальної соціально-емоційної незрілості; 2 група - діти з переважаючим дефіцитом пізнавальних і соціальних здібностей, в структурі порушення яких на перший план виступає недостатність розвитку не тільки регуляторної, а й когнітивної сфери, що виявляється на тлі порушень коркової нейродинаміки, зниженої розумової працездатності, афективно-поведінкових розладів; 3 група - діти з вираженою затримкою розвитку когнітивних та соціальних здібностей (легкий психічний недорозвиток), що характеризується значно нижчим порівняно з віковою нормою рівнем інтелектуального розвитку, який за якісними характеристиками своєї структури (недорозвинення складних форм розумової діяльності) 


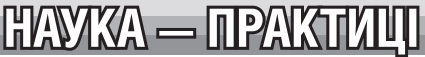

наближається до феноменології легкої розумової відсталості, і має виразні ознаки церебрально-органічної недостатності.

Отже, для оптимального розвитку дошкільника із затримкою психічного розвитку важливою є усвідомлена комунікативна діяльність, яка забезпечує здатність до взаємодії з різними психологічними системами та творення співбуттевого стосунку. З'ясування іï особливостей необхідно здійснювати 3 дотриманням низки принципів, зокрема структурно-генетичного, суб'єктності, культурного контекстуалізму, онтологічного конструктивізму, інтеграції, єдності методологічних, діагностичних, корекційно-розвивальних і психокорекційних інтервенцій; диференціаціального підходу.

Таким чином, екзистенціально-суб'єктний науковий підхід можна визнати оптимальним у формулюванні концептуальних уявлень про феноменологію $\mathrm{i}$ ноуменологію комунікативної діяльності у вимірі Я-Інший (Я-Інший Я). Методологічні орієнтири зазначеного підходу стануть підгрунтям для розроблення й апробації експериментальної моделі дослідження комунікативної діяльності у вимірі Я-Інший (Я-Інший Я) у дошкільників із затримкою психічного розвитку.

\section{ЛITEPATУPA}

1. Большунова Н. Я. Субъектность как социокультурное явление. Новосибирск : Издательство НГГУ, 2005.- 324 с.

2. Волкова Е. Н. Субъектность педагога: теория и практика: автореф. дис... доктора психол. наук: 19.00.07. Москва, 1998.- 50 с.

3. Воробъева Л. И. Диалог и коммуникация. Московский психотерапевтический журнал. 2006. № 2.- C. 5-28.

4. Дьяконов Г. В. Психологія діалогу: гіпотези емпіричного дослідження. Психологія і особистість. 2015. № 2 (2).- С. 6-20.

5. Знаков B. В. Три традиции психологических исследований - три типа понимания. Вопросы психологии. 2009. № 4.- С.14-23.

6. Зубова Д. А. Феномен субъектности в пространстве современной философской рефлексии: диссертация ... кандидата философских наук : 09.00.01 [Место защиты: Юж. федер. ун-т]. Ростов-на-Дону, 2011. -157 с. : ил.

7. Кобыльченко B. В. Проблема психологической диагностики детей с отклонениями в развитии: теоретические аспекты. Естественно-научный подход в современной психологии. Москва: Изд-во «Институт психологии РАН», 2014.- С. 829 - 835.

8. Лубовский В. И., Новикова Г. Р., Налимов В. Ф. Принципы диагностики психического дизонтогенеза и клиническая систематика задержки психического развития. Дефектология. 2011. №5.- С. 17-26.

9. Непомнящая Н. И. Становление личности ребенка 6-7 лет. Москва : Педагогика, 1992.- 160 с.

10. Омельченко I. M. Комунікативна діяльність у структурі свідомості та самосвідомості:феноменологія і ноуменологія. Психологія і особистість. 2018. №1 (13).- С. 20-35.

11. Прохоренко Л. І. Діагностика саморегуляції навчальної діяльності школярів із затримкою психічного розвитку. Особлива дитина: навчання і виховання. 2016. № 3 (79).- С. 36-44.

12. Савчин М. Методологеми психології. Київ : Академвидав, 2013. 224 с.

«ОСОБЛИВА ДИТИНА: навчання і виховання», № 4, 2018 
13. Tiтов I. Г. Взаимосвязь онтологического, гносеологического, аксиологического и праксиологического аспектов личностного бытия. Філософські обрії. 2012. № 28.- С. 124-134.

14. Титов И. Г. Постнекласическая личность. Методологические основания психологического исследования. LAP Lambert Academic Publishing, 2014.- 124 c.

15. Устинова О. А. Развитие «образа-Я» посредством внутреннего диалога ребенка с миром. Сибирский педагогический журнал 2010. № 6.- С. 257-264.

\section{REFERENCES (TRANSLATED AND TRANSLITERATED)}

1. Bolshunova, N. Ya. (2005). Subektnost kak sociokulturnoe yavlenie. Novosibirsk: Izdatelstvo NGGU. [In Russian].

2. Volkova, E. N. (1998). Subektnost pedagoga: teoriya i praktika. Extended abstract of candidate's thesis. 19.00.07. Moskva [In Russian].

3. Vorobeva, L. I. (2006). Dialog i kommunikaciya. Moskovskij psihoterapevticheskij zhurnal, 2, pp. 5-28. [In Russian].

4. Dyakonoz, G. V. (2015). Psihologiya dialogu: gipotezi empirichnogo doslidzhennya. Psychology and personality, 2 (2), pp. 6-20. [In Ukrainian].

5. Znakov, V. V. (2009). Tri tradicii psihologicheskih issledovanij - tri tipa ponimaniya. Voprosy psikhologii, 4, pp.14-23. [In Russian].

6.Zubova,D.A.(2011). Fenomen subektnostiv prostranstvesovremennoj filosofskoj refleksii:Candidate's thesis filosofskih nauk : 09.00.01 [Mesto zashity: Yuzh. feder. un-t]. Rostov-na-Donu. [In Russian].

7. Kobylchenko, V. V. (2014). Problema psihologicheskoj diagnostiki detej s otkloneniyami v razvitii: teoreticheskie aspekty. Estestvenno-nauchnyj podhod v sovremennoj psihologii. Moskva Izd-vo «Institut psihologii RAN». [In Russian].

8. Lubovskij, V. I., Novikova, G. R., Shalimov, V. F. (2011). Principy diagnostiki psihicheskogo dizontogeneza i klinicheskaya sistematika zaderzhki psihicheskogo razvitiya. Defektologiya, 5, pp. 17-26. [In Russian].

9. Nepomnyashaya, N. I. (1992). Stanovlenie lichnosti rebenka 6-7 let. Moskva : Pedagogika. [In Russian].

10. Omelchenko, I. M. (2018). Komunikatyvna diyalnist u strukturi svidomosti ta samosvidomosti:fenomenologiya i noumenologiya. Psychology and personality. 1(13), pp. 20-35. [In Ukrainian].

11. Proxorenko, L. I. (2016). Diagnostyka samoregulyaciyi navchalnoyi diyalnosti shkolyariv iz zatrymkoyu psyxichnogo rozvytku. Exceptional Child: Teaching and Upbringing, 3 (79), pp. 36-44. [In Ukrainian].

12. Savchyn, M. (2013). Metodologemy psyxologiyi. Kyyiv: Akademvydav. [In Ukrainian].

13. Titov, I. G. (2012). Vzaimosvyaz ontologicheskogo, gnoseologicheskogo, aksiologicheskogo i praksiologicheskogo aspektov lichnostnogo bytiya. Filosofski obriyi, 28, pp. 124-134. [In Russian].

14. Titoz, I. G. (2014). Postneklasicheskaya lichnost. Metodologicheskie osnovaniya psihologicheskogo issledovaniya. LAP Lambert Academic Publishing. [In Russian].

15. Ustinova, O. A. (2010). Razvitie «obraza-Ya» posredstvom vnutrennego dialoga rebenka s mirom. Sibirskij pedagogicheskij zhurnal, 6, pp. 257-264. [In Russian]. 